Agricultural Insects of East Africa

Compiled by R. H. Le Pelley. Pp. $x+307$. (Nairobi : East Africa High Commission, 1959.) $42 s$.

$T^{\text {NTOMOLOGISTS and agriculturalists in many }}$ A tropical countries, particularly in Africa, have been greatly handicapped because they have not been able to refer to authoritative lists giving the names of insects recorded there. A great deal of the information required has been collected by Government entomologists, and has been buried in departmental files. Dr. Le Pelley has performed a useful service in bringing together in this book so many records of insects and mites associated with plants in Kenya, Uganda, Tanganyika and Zanzibar ; workers here, in adjacent territories and even in other parts of tropical and sub-tropical Africa, will find the lists invaluable. Parasites, predators and stored products insects are included, with the original reference to the publication first giving their occurrence. A list like this cannot but be incomplete, as its author would be the first to point out; but he is to be sincerely congratulated on his success in including so many records others would not have unearthed.

The title, "Agricultural Insects of East Africa", may mislead. This book contains only a list of names of insects and plants. It does not give any descriptions of the animals, or of their importance in agriculture. It is a very valuable work as it stands, and it is perhaps unfortunate that the title does not make its nature more obvious.

Kenneth Mellanby

A Laboratory and Field Manual of Ornithology By Olin Sewall Pettingill, Jr. Third edition, second printing. Pp. viii +279 . (Minneapolis : Burgess Publishing Company; London: Mayflower Publishing Co., Ltd., 1958.) $40 s$.

TN recent years ornithology has become increasingly 1 respectable among contemporary sciences without losing its place as a source of casual interest and amusement. This status has been achieved to a large extent by improvements in standards of teaching as reflected in such books as this laboratory and field manual. In Britain it seems difficult to isolate ornithology as a special subject in the curricula of secondary schools and universities, and teaching is confined mainly to extra-mural environments. But in the United States, apparently, this difficulty is not felt to the same extent, for Prof. Pettingill's manual is based on notes for lectures at high schools and colleges. The text consists of explanatory material and directions for study, including lines of research for advanced students. Although retaining the form and structure of lecturer's notes (it is a photo-offset reproduction of typescript) it is a valuable source of useful information on most aspects of bird biology.

J. D. MACDONALD

\section{The Buzzard}

Text and Photographs by Frank Wenzel. Translated from the Danish by Reginald Spink. Pp. 86. (London : George Allen and Unwin, Ltd., 1959.) 35s. net.

1 HIS book trom Denmark, written and illustrated by Frank Wenzel, is a fine example of bird photography. Its illustrations from photographs in colour and in black-and-white include many superb pictures, some of remarkable dramatic quality, for example the colour plate facing p. 80. This shows a buzzard balancing itself with extended wings held aloft on a swaying branch. The bird is silhouetted against a stormy sky with a dazzling sun gleaming from between the clouds. Another pleasing picture is the portrait of a buzzard facing p. 73. It shows a remarkably light-coloured bird in a green woodland setting and it reminds us how this species varies in colour and markings. A little farther on is a photograph of a very dark male, with plumage of deep sooty brown, indeed almost black.

The letterpress is comparatively slight; but it is based on first-hand observations, telling of the author's experiences among the buzzards of his native Denmark. He gives us many exciting descriptions of its woods, heaths and marshes. He tells how he built a hide in a tree from which he could see into a buzzard's nest in a neighbouring tree ; he adds he thought it desirable to ensconce himself in it under cover of darkness, though to do so he had to walk through the night-time woods. "Moonlight makes everything change character," he says. "Things well known in daylight now appear quite unfamiliar. Tree trunks look like dark figures throwing long mysterious shadows in the undergrowth; harmless stumps are transformed into witches and ogres. The silence was broken over by the bog. There was a strange purring and whirring noise ... it was the phantom nightjar filling the night with magie and mystery."

This volume would make a fine present for any young person with aspirations to use his camera in the portrayal of birds.

Frances Pitr

Diseases of Farm Crops

By A. Beaumont. Pp. $128+48$ photographs. (London : W. H. and L. Collingridge, Ltd., 1959.) $25 s$. net.

7 HE farmers and agricultural students for whom the author intends this companion volume to his "Diseases of Garden Plants" will be glad that it is written so clearly, with so few scientific terms and generously illustrated by photographs nearly all of which show what is intended. Readers better versed in plant pathology will recognize that most of the recent work is mentioned in summaries of the major diseases. The author is realistic about the importance of diseases, and the control measures necessary or practical; he emphasizes the effects of crop rotation and has added many cautionary notes born of his long experience as an advisory plant pathologist.

Because much of it is good, the weaker parts of the book stand out starkly. The arrangement of diseases under crops and the organs attacked makes reference easy, but leads to much repetition which could be avoided by tabulation or some grouping of closely related hosts. The too-simple section on naming and recognition of diseases, the many notes on rare fungi and, for example, the 15 references under marrow stem kale which contain little more than notes of frequency and cross-references, all make one wish the author had used this space to expand the sections on principles and major diseases. J. M. HiRsT

\section{A Handbook of West African Flowers}

By Harold N. Saunders. Pp. 124. (London: Oxford University Press, 1958.) 5s.

TT is not an easy task to select the commonest 1 plants in an area, and the larger the area the more difficult it becomes. When the area is West Africa from Gambia to Nigeria, with a flora of several 